\title{
Addition of biostimulant to the industrial treatment of soybean seeds: physiological quality and yield after storage ${ }^{1}$
}

\author{
Lucas Caiubi Pereira ${ }^{2 *}$, Thaisa Cavalieri Matera², Alessandro Lucca Braccini², \\ Renata Cristiane Pereira ${ }^{2}$, Danilo Cesar Volpato Marteli², Andreia Kazumi Suzukawa², \\ Samara Cavalli Piana ${ }^{2}$, Gláucia Cristina Ferri ${ }^{2}$, Larissa Vinis Correia ${ }^{2}$
}

\begin{abstract}
This study aimed to compare the results of germination, vigor, and yield of high- and low-vigor soybean seeds submitted to on-farm application of biostimulant with its application via industrial treatment 60 days before sowing. The experimental design was a factorial arrangement of $6 \times 2 \times 2$ (technology $\times$ vigor level $\times$ strategy of biostimulant application) for the laboratory experiment and of $6 \times 2$ (technology $\times$ strategy of biostimulant application) for the field experiment. Germination, accelerated aging, emergence in sand, seedling dry biomass, and electrical conductivity were assessed in the laboratory, while stand, one thousand-grain weight, and yield were assessed in the field. Biostimulant application in soybean seeds not coated with pesticides did not affect the physiological quality regardless of the application moment (at the day of sowing or at 60 days before sowing). However, when applied in seeds coated with fungicides and insecticides, better results of germination, vigor, and yield were obtained with the on-farm use of biostimulant.
\end{abstract}

Index terms: Glycine max, bioregulator, vigor, germination, productivity.

\section{Adição de bioestimulante ao tratamento industrial de sementes de soja: qualidade fisiológica e produtividade após o armazenamento}

\begin{abstract}
RESUMO - Objetivou-se com o presente trabalho comparar os resultados de germinação, vigor e produtividade da cultura da soja obtidos com sementes de soja de alto e baixo vigor que foram submetidas a aplicação on farm de bioestimulante e com a deste mesmo produto via tratamento industrial 60 dias antes da semeadura. O delineamento experimental adotado foi em esquema fatorial de 6 × 2 × 2 (tecnologia x nível de vigor e estratégia de aplicação de bioestimulante) para o ensaio de laboratório e de 6 × 2 (tecnologia $\mathrm{x}$ estratégia de aplicação de bioestimulante) para o ensaio de campo. Em laboratório foram avaliados a germinação, o envelhecimento acelerado, a emergência em areia, a biomassa seca de plântulas e condutividade elétrica; ao passo que no campo foram avaliados o estande, a massa de mil grãos e a produtividade. A aplicação de bioestimulante em sementes de soja não revestidas com defensivos agrícolas não prejudicou a qualidade fisiológica, independentemente do momento da aplicação (no dia ou 60 dias antes da semeadura). Todavia, quando aplicado em sementes recobertas com fungicidas e inseticidas, resultados superiores de germinação, vigor e produtividade foram obtidos com o uso on farm do bioestimulante.
\end{abstract}

Termos para indexação: Glycine max, biorregulador, vigor, germinação, produtividade.

\section{Introduction}

The use of kinetin, auxin, and gibberellic acid-based biostimulants in soybean cultivation via seed treatment or foliar spraying in the V5-V6 or R1 stages are cultural practices considered equivalent both in crop yield and in obtaining high-quality grains (Bertolin et al., 2010; Embrapa, 2013a). Auxins influence cell expansion mechanisms, cytokinins are

\footnotetext{
${ }^{1}$ Submitted on $05 / 16 / 2018$. Accepted for publication on $08 / 20 / 2018$.

${ }^{2}$ Departamento de Agronomia, Universidade Estadual de Maringá, 87020-900 - Maringá, PR, Brasil.

*Corresponding author <lucascaiubi@yahoo.com.br>
} 
linked to nutrient mobilization and floral development, while gibberellins are associated with the promotion of stem growth (Taiz and Zeiger, 2013).

In this sense, the observation of the positive response of soybean crop to biostimulant application in three different phenological stages (seeds, V5-V6 or R1) is explained by the difference in the metabolic processes in which each of the hormones participates. However, these substances do not act alone on the plants since the tissues on which they are applied contain endogenous hormones, which, together with those externally applied, contribute to plant growth and development (Taiz and Zeiger, 2013).

Because of the small required volume, biostimulants are potentially compatible with the industrial seed treatment, an industrial scale process that provides adequate dose precision, uniformity of seed coating, and increases the adhesion of the applied products (Menten and Moraes, 2010). In the most recent survey, it is estimated that $95 \%$ of the soybean seeds sown in the country's producing regions were treated with fungicides and/or insecticides so that approximately $66 \%$ of the total commercialized corresponded to the industrial treatment (França-Neto et al., 2015).

However, once seed processing is carried out before sowing, industrial treatment requires an anticipation of demand and, once treated, seeds are stored until the commercialization (Menten and Moraes, 2010). Therefore, it is a recurrent practice by the seed industry of large crops to carry out the treatment no more than 60 days before the start of sowing in order to minimize possible deleterious effects that the used spraying solutions may have on germination and vigor of seeds (Zambon, 2013; Strieder et al., 2014).

However, little is known about the effect that the addition of biostimulants to industrial treatments can provide on the physiological performance of seeds over the storage time. In this sense, the hypothesis of this study is that the use of biostimulant via industrial treatment of soybean seeds 60 days before sowing results in a yield and physiological quality equivalent to applications performed on-farm either via foliar or via seeds before sowing. Thus, this study aimed to compare the results of germination, vigor, and yield of soybean seeds submitted to the on-farm application of biostimulant with its application via industrial treatment carried out 60 days before sowing.

\section{Material and Methods}

In this study, we used two vigor levels of the soybean cultivar BMX Potência RR, classified as having an indeterminate growth habit and belonging to the semi-precocious maturation group (6.7). These seeds were industrially treated with fungicides, insecticides, polymers, dry powders, and fertilizers, which together are commonly called technologies. The active ingredients and their respective commercial products and doses are described below and summarized in Table 1.

Technology I: pyraclostrobin $25 \mathrm{~g}$. $\mathrm{L}^{-1}+$ thiophanatemethyl 225 g. L $\mathrm{L}^{-1}+$ fipronil 250 g. L L ${ }^{-1}$ (Standak Top ${ }^{\circledR}, 200$ mL. $100 \mathrm{~kg}^{-1}$ ), polymer (Disco Ag Green ${ }^{\circledR}, 200 \mathrm{~mL} .100 \mathrm{~kg}^{-1}$ ), micronutrients (CoMo Plantinum ${ }^{\circledR}, 200 \mathrm{~mL} .100 \mathrm{~kg}^{-1}$ ), and dry powder (Fluidus ${ }^{\circledR}, 350$ g. $100 \mathrm{~kg}^{-1}$ ).

Technology II: carbendazim $150 \mathrm{~g}$. $\mathrm{L}^{-1}+$ thiram $350 \mathrm{~g}$. $\mathrm{L}^{-1}$ (Derosal Plus ${ }^{\circledR}, 200 \mathrm{~mL} .100 \mathrm{~kg}^{-1}$ ), imidacloprid $150 \mathrm{~g}$. $\mathrm{L}^{-1}+$ thiodicarb 450 g. $\mathrm{L}^{-1}\left(\right.$ Cropstar $^{\circledR}, 500 \mathrm{~mL} .100 \mathrm{~kg}^{-1}$ ), micronutrients (CoMo Plantinum ${ }^{\circledR}, 200 \mathrm{~mL} .100 \mathrm{~kg}^{-1}$ ), polymer (Peridiam $306^{\circledR}, 200 \mathrm{~mL} .100 \mathrm{~kg}^{-1}$ ), and dry powder (Fluency Powder ${ }^{\circledR}, 450$ g. $100 \mathrm{~kg}^{-1}$ ).

Table 1. Summary of soybean seed treatments with their respective volumes.

\begin{tabular}{|c|c|c|c|c|c|}
\hline Technology & Treat. & $\begin{array}{c}\text { Biostimulant } \\
\text { application strategy }\end{array}$ & $\begin{array}{l}\text { Days between the industrial } \\
\text { treatment and sowing }\end{array}$ & $\begin{array}{c}\text { Volumes } \\
\left(\mathrm{mL} .100 \mathrm{~kg}^{-1}\right)\end{array}$ & Nomenclature \\
\hline Control & 1 & Foliar in $\mathrm{V}_{5}$ & -- & 0 & Control or Bio FL \\
\hline \multirow{2}{*}{ Untreated seeds } & 2 & On-farm & -- & 500 & Bio OF \\
\hline & 3 & Early & -- & 500 & Bio BS \\
\hline \multirow{2}{*}{ Technology I } & 4 & On-farm & 1 & 1100 & Technology I + Bio OF \\
\hline & 5 & Early & 60 & 1100 & Technology I + Bio BS \\
\hline \multirow{2}{*}{ Technology II } & 6 & On-farm & 1 & 1600 & Technology II + Bio OF \\
\hline & 7 & Early & 60 & 1600 & Technology II + Bio BS \\
\hline \multirow{2}{*}{ Technology III } & 8 & On-farm & 1 & 1800 & Technology III + Bio OF \\
\hline & 9 & Early & 60 & 1800 & Technology III + Bio BS \\
\hline \multirow{2}{*}{ Technology IV } & 10 & On-farm & 1 & 1300 & Technology IV + Bio OF \\
\hline & 11 & Early & 60 & 1300 & Technology IV + Bio BS \\
\hline \multirow{2}{*}{ Technology V } & 12 & On-farm & 1 & 1200 & Technology V + Bio OF \\
\hline & 13 & Early & 60 & 1200 & Technology V + Bio BS \\
\hline
\end{tabular}

Journal of Seed Science, v.40, n.4, p.442-449, 2018 
Technology III: the same products and doses of Technology II, but with a higher dose of the insecticide imidacloprid 150 g. $\mathrm{L}^{-1}+$ thiodicarb $450 \mathrm{~g}$. $\mathrm{L}^{-1}$ (Cropstar $^{\circledR}$, $700 \mathrm{~mL} .100 \mathrm{~kg}^{-1}$ ).

Technology IV: carbendazim $150 \mathrm{~g}$. $\mathrm{L}^{-1}+$ thiram $350 \mathrm{~g}$. $\mathrm{L}^{-1}$ (Derosal Plus ${ }^{\circledR}, 200 \mathrm{~mL} .100 \mathrm{~kg}^{-1}$ ), chlorantraniliprole 625 g. $\mathrm{L}^{-1}$ (Dermacor ${ }^{\circledR}, 200 \mathrm{~mL} .100 \mathrm{~kg}^{-1}$ ), micronutrients $\left(\right.$ CoMo Plantinum ${ }^{\circledR}, 200 \mathrm{~mL} .100 \mathrm{~kg}^{-1}$ ), polymer (Peridiam $306^{\circledR}, 200 \mathrm{~mL} .100 \mathrm{~kg}^{-1}$ ), and dry powder (Fluency Powder ${ }^{\circledR}$, 450 g. $\left.100 \mathrm{~kg}^{-1}\right)$.

Technology V: metalaxyl-m 10 g. $\mathrm{L}^{-1}+$ fludioxonil $25 \mathrm{~g}$. $\mathrm{L}^{-1}$ (Maxim Advanced $^{\circledR}, 100 \mathrm{~mL} .100 \mathrm{~kg}^{-1}$ ), thiamethoxam $350 \mathrm{~g} . \mathrm{L}^{-1}$ (Cruiser $350 \mathrm{FS}^{\circledR}, 200 \mathrm{~mL} .100 \mathrm{~kg}^{-1}$ ), abamectin $500 \mathrm{~g} . \mathrm{L}^{-1}$ (Avicta $500 \mathrm{FS}^{\circledR}, 100 \mathrm{~mL} .100 \mathrm{~kg}^{-1}$ ), micronutrients (CoMo Plantinum ${ }^{\circledR}$, $200 \mathrm{~mL} .100 \mathrm{~kg}^{-1}$ ), polymer (Disco Ag Green ${ }^{\circledR}, 100 \mathrm{~mL} .100 \mathrm{~kg}^{-1}$ ), and dry powder (Fluidus ${ }^{\circledR}, 150 \mathrm{~g} .100 \mathrm{~kg}^{-1}$ ).

In the early strategy carried out 60 days before sowing, each technology was industrially combined with the application of a biostimulant based on $0.009 \%$ kinetin + $0.005 \%$ auxin $+0.005 \%$ gibberellic acid (Stimulate ${ }^{\circledR}, 500$ $\mathrm{mL} .100 \mathrm{~kg}^{-1}$ ) (Bio BS). On the other hand, in the on-farm strategy, the biostimulant was applied just before sowing (Bio OF) using seeds industrially treated with fungicides and insecticides the day before the tests were installed. Regardless of the strategy, after the industrial treatment, seeds were packed in kraft paper bags and maintained at a temperature of $22{ }^{\circ} \mathrm{C}$ and an average relative humidity of $66 \%$.

In addition to the mentioned combinations, we also used an untreated control with a biostimulant applied via foliar in the V5 stage (Bio FL) and other two treatments with seeds not treated with fungicide and insecticide: the first called on-farm, in which the biostimulant application occurred just before sowing (Bio OF), and the second via industrial seed treatment at 60 days before sowing (Bio BS).

In order to optimize the data analysis, biostimulant application (strategies) and consequently their respective storage periods ( 0 and 60 days) were called on-farm and early strategies. This same designation was adopted in the classification of the two levels of tested vigor. This statistical procedure is commonly used in the human and social sciences areas since it allows summarizing and categorizing a complex or varied set of data into qualitative information (Saldana, 2009). Therefore, the encodings included the following parameters:

i) High vigor: a lot with seeds not treated with fungicide and insecticide of the cultivar BMX Potência RR with germination of $91 \%$, emergence in sand of $98 \%$, electrical conductivity of $85.46 \mu \mathrm{S} \mathrm{cm}^{-1} \mathrm{~g}^{-1}$, accelerated aging of $75 \%$, field emergence of $92 \%$, and seedling dry biomass of $0.1851 \mathrm{~g}$.

ii) Low vigor: the same high-vigor seeds, but artificially aged according to the methodology described below. The seeds were maintained in a water-jacketed chamber at 41 $\pm 1{ }^{\circ} \mathrm{C}$ for only $24 \mathrm{~h}$, resulting in a germination of $85 \%$, emergence in sand of $90 \%$, electrical conductivity of 149.56 $\mu \mathrm{S} \mathrm{cm} \mathrm{c}^{-1} \mathrm{~g}^{-1}$, accelerated aging of $62 \%$, field emergence of $81 \%$, and seedling dry biomass of $0.141 \mathrm{~g}$.

iii) On-farm strategy: manual biostimulant application one hour before sowing (time zero) using seeds industrially treated with fungicide and insecticide (on the previous day). For this, these seeds were conditioned in plastic bags to receive the product dosage and then shaken for approximately $1 \mathrm{~min}$.

iv) Early strategy: biostimulant application during the industrial treatment of seeds, which were then stored under laboratory conditions (ambient temperature of $22{ }^{\circ} \mathrm{C}$ and average relative humidity of $66 \%$ ) over 60 days before being used.

\section{Laboratory experiment}

The tests of germination, accelerated aging, emergence in sand, seedling dry biomass, and electrical conductivity were carried out in the laboratory according to the methodologies described below:

Germination: conducted with eight subsamples of 50 seeds for each treatment and analytical replication, as recommended by the Rules for Seed Testing (Brasil, 2009).

Accelerated aging: four subsamples of 50 seeds per treatment and analytical replication were submitted to a temperature of $41 \pm 1{ }^{\circ} \mathrm{C}$ for $48 \mathrm{~h}$ in a VWR/USA waterjacketed chamber model 3015, as proposed by MarcosFilho (1999). Subsequently, these seeds were submitted to the germination test according to Brasil (2009), but with the assessment performed on the fifth day after the experiment was installed.

Emergence in sand: the test was performed by sowing eight subsamples of 50 seeds per treatment in trays containing washed sand, as the Nakagawa (1999) methodology. In the experiment installation, the substrate was moistened with water corresponding to $60 \%$ of the retention capacity. The results were expressed as an average percentage.

Seedling dry biomass: eight subsamples of 20 seeds per treatment were distributed in rolls of paper towel (Germitest ${ }^{\mathbb{R}}$ ) moistened with distilled water in the 3:1 ratio $(\mathrm{mL}$ of distilled water to mass of dry paper in grams). These seeds were maintained in a Mangelsdorf germinator at $25 \pm 2{ }^{\circ} \mathrm{C}$ for seven days (Nakagawa, 1999). Subsequent to cotyledon discard, seedlings were dried in a forced air circulation oven at $65{ }^{\circ} \mathrm{C}$ until constant weight. The average dry biomass was obtained by weighing the seedlings in an analytical balance (0.0001 g) (Nakagawa, 1999). 


\section{Field experiment}

The field experimental was installed in October 2016 by using the high-vigor seed lot at the Experimental Farm Iguatemi $\left(23^{\circ} 25^{\prime} \mathrm{S}\right.$ and $51^{\circ} 57^{\prime} \mathrm{W}$, with an average altitude of $540 \mathrm{~m}$ ) of the Universidade Estadual de Maringá (UEM), Maringá, Paraná State, Brazil. The predominant regional climate is Cfa, i.e. a humid mesothermal climate with abundant precipitation in the summer, a dry winter, and warm summer, as Köppen classification (Caviglione et al., 2000).

The cultivation area has a history of succession with corn in the summer and canola or wheat in the winter. The soil of the experimental area is classified as an Ultisol (Argissolo Vermelho distroférrico, Brazilian Soil Classification System) (Embrapa, 2013b). The results of the chemical analysis in the 0-20 $\mathrm{cm}$ layer before experiment setup were a $\mathrm{pH}\left(\mathrm{CaCl}_{2}\right)=$ 4.78, P (Mehlich-1) $=4.18 \mathrm{mg} . \mathrm{dm}^{-3}, \mathrm{H}^{+}+\mathrm{Al}^{3+}=2.49 \mathrm{cmol}_{\mathrm{c}}$. $\mathrm{dm}^{-3}, \mathrm{Al}^{3+}=1.05 \mathrm{cmol}_{\mathrm{c}} \cdot \mathrm{dm}^{-3}, \mathrm{~K}^{+}=0.65 \mathrm{cmol}_{\mathrm{c}^{\prime}} \cdot \mathrm{dm}^{-3}, \mathrm{Ca}^{2+}=$ $3.63 \mathrm{cmol}_{\mathrm{c}} \cdot \mathrm{dm}^{-3}, \mathrm{Mg}^{2+}=2.58 \mathrm{cmol}_{\mathrm{c}} \cdot \mathrm{dm}^{-3}, \mathrm{CEC}=9.35 \mathrm{cmol}_{\mathrm{c}}$. $\mathrm{dm}^{-3}$, and $\mathrm{V}=73.39 \%$. The particle size analysis for the same soil layer showed $14.20 \%$ of coarse sand, $37.3 \%$ of fine sand, $0.95 \%$ of silt, and $47.55 \%$ of clay.

The installation and conduction of the experimental field were carried out according to Embrapa (2013a) recommendations. The conventional tillage system was carried out 15 days before the experiment setup. Based on the soil analysis, $350 \mathrm{~kg}$. ha ${ }^{-1}$ of the formulation $0-20-20$ was mechanically incorporated into the soil at sowing time. A dose of $50 \mathrm{~g}$. $\mathrm{kg}^{-1}$ of seeds of a commercial Bradyrhizobium japonicum based peat inoculum was applied just before sowing in all treatments (Strains Semia 5079 and Semia 5080).

Plots consisted of seven rows of $5 \mathrm{~m}$ in length spaced $0.45 \mathrm{~m}$ from each other, with a sowing depth of approximately $3 \mathrm{~cm}$ and a density of 20 seeds per square meter. The two outer rows were discarded at harvest, as well as $0.5 \mathrm{~m}$ from each end of the central rows. The analyzed response variables in the field trial were:

Stand: the number of plants present in each useful row of the plot was counted at 15 days after sowing. The result was expressed as the average number of plants per square meter.

Grain yield: determined by harvesting all plants from the useful area of each plot. The plants were manually harvested when at least $95 \%$ of the pods had the typical mature pod coloration. Once harvested, the pods were threshed in a stationary thresher to obtain the seeds. Subsequently, the grains were weighed in a scale of one decimal place. Water content and yield were then determined, being corrected to 13\% (Brasil, 2009).

One thousand-grain weight: determined by weighing, in a one-milligram precision scale, eight subsamples of 100 grains for each field replication and multiplying the results by 10. The weight was corrected to $13 \%$ wet basis (Brasil, 2009).

The experimental design of the laboratory experiment was a completely randomized design in a $6 \times 2 \times 2$ factorial scheme with four replications: six technologies (untreated seed and technologies I, II, III, IV, and V) $\times$ two vigor levels (high and low) $\times$ two biostimulant application strategies (on-farm and early). The only exception was the variable field emergence, in which the experimental design was a randomized complete block design with four replications.

For the field experiment, the experimental design was a randomized complete block design in a $6 \times 2$ factorial scheme with four replications: six technologies (untreated seed and technologies I, II, III, IV, and V) $\times$ two biostimulant application strategies (on-farm and early). However, only the high-vigor lot was used in this experiment.

The obtained results were submitted to analysis of variance when meeting the basic assumptions (errors usually distributed with zero mean and common variance). For this, we used the Shapiro-Wilk test for normality and the Levene test for homogeneity of residual variances (Banzatto and Kronka, 2008). Except for the field variables, as well as electrical conductivity and seedling dry biomass, all the other variables presented heterogeneity of variances requiring the data transformation into arcsin $\sqrt{x / 100}$. However, the original mean values were used in the tables.

\section{Results and Discussion}

In relation to the physiological quality, no adverse effects of the biostimulant were observed on the germination and vigor of high-vigor seeds not treated with fungicide and insecticide (treatments 1, 2, and 3) (Table 2). On the other hand, with the exception of germination and seedling dry biomass in treatments 2 (Bio OF) and 3 (Bio BS), the early biostimulant application in low-vigor seeds resulted in reductions of the physiological quality, as observed by means of the tests of germination, emergence in sand, electrical conductivity, accelerated aging, field emergence, and seedling dry biomass.

Regarding the seeds treated with pesticides, with the exception of Technology IV for germination and accelerated aging and Technology III for electrical conductivity (Table 2), the early strategy resulted in reductions of germination and vigor of seeds regardless of the active ingredient or initial vigor class of the lot. However, more pronounced reductions in germination and vigor were observed in the treatments based on Technology III, in which the fungicide carbendazim/ thiram was used with the highest dose of the insecticide 
imidacloprid/thiodicarb. In this case, the deleterious effects on germination and vigor were aggravated in the interaction with the factors low vigor and/or early application (Table 2).

Several authors have reported adverse effects of imidacloprid on the physiological seed quality, especially during storage (Dan et al., 2010; Dan et al., 2011; Avelar et al., 2011; Pereira et al., 2018). However, it is not possible to attribute to an active ingredient all the detrimental effects observed in seeds since the conservation of a lot depends on several factors, such as the initial vigor, cultivar sensitivity, and the solution volume (Santos et al., 2018). Therefore, in addition to the possible phytotoxic nature of imidacloprid/ thiodicarb, used in Technologies II and III, the solution volume $12.5 \%$ higher in latter technology (a result of the insecticide dose $40 \%$ higher, according to the manufacturer's recommendation for controlling Meloidogyne javanica or Pratylenchus brachyurus) may have contributed, at least partially, to considerably inferior results.

In contrast, Segalin et al. (2013) reported that in industrial treatments based on carbendazim/thiram + imidacloprid/

Table 2. Means for germination (G), emergence in sand (EM), electrical conductivity (EC), accelerated aging (AA), field emergence (FE), and seedling dry biomass (SDB) of soybean seeds of the cultivar BMX Potência RR as a function of the treatment on-farm with biostimulant just before sowing (Bio OF) and early application of biostimulant via industrial treatment at 60 days before experiment setup (Bio BS).

\begin{tabular}{|c|c|c|c|c|c|c|c|}
\hline & \multirow{2}{*}{ Treatment } & \multicolumn{2}{|c|}{$\mathrm{G}(\%)$} & \multicolumn{2}{|c|}{ EM (\%) } & \multicolumn{2}{|c|}{$\mathrm{EC}\left(\mu \mathrm{S} \mathrm{cm}^{-1} \mathrm{~g}^{-1}\right)$} \\
\hline & & High vigor & Low vigor & High vigor & Low vigor & High vigor & Low vigor \\
\hline 1 & Control & $91 \mathrm{Aa}$ & $85 \mathrm{Ab}$ & $98 \mathrm{Aa}$ & $90 \mathrm{Ab}$ & $85.46 \mathrm{Aa}$ & $149.56 \mathrm{Ab}$ \\
\hline 2 & Bio OF & $92 \mathrm{Aa}$ & $83 \mathrm{Ab}$ & $97 \mathrm{Aa}$ & $89 \mathrm{Ab}$ & $86.15 \mathrm{Aa}$ & $150.64 \mathrm{Ab}$ \\
\hline 3 & Bio BS & $90 \mathrm{Aa}$ & $78 \mathrm{Ab}$ & $98 \mathrm{Aa}$ & $85 \mathrm{Bb}$ & $87.43 \mathrm{Aa}$ & $161.45 \mathrm{Bb}$ \\
\hline 4 & Tech I + Bio OF & $91 \mathrm{Aa}$ & $79 \mathrm{Bb}$ & $94 \mathrm{Ba}$ & $80 \mathrm{Cb}$ & $110.31 \mathrm{Ba}$ & $163.56 \mathrm{Bb}$ \\
\hline 5 & Tech I + Bio BS & $88 \mathrm{Ba}$ & $73 \mathrm{Cb}$ & $83 \mathrm{Da}$ & $77 \mathrm{~Eb}$ & $124.05 \mathrm{Ca}$ & $198.64 \mathrm{~Eb}$ \\
\hline 6 & Tech II + Bio OF & $84 \mathrm{Ca}$ & $76 \mathrm{Cb}$ & $95 \mathrm{Ba}$ & $82 \mathrm{Bb}$ & $132.75 \mathrm{Da}$ & $164.45 \mathrm{Bb}$ \\
\hline 7 & Tech II + Bio BS & $88 \mathrm{Ba}$ & $67 \mathrm{Db}$ & $86 \mathrm{Ca}$ & $79 \mathrm{Db}$ & 137.49 Da & $187.49 \mathrm{Db}$ \\
\hline 8 & Tech III + Bio OF & $77 \mathrm{Da}$ & $57 \mathrm{~Eb}$ & $88 \mathrm{Ca}$ & $75 \mathrm{~Eb}$ & $143.58 \mathrm{Ea}$ & $210.34 \mathrm{~Eb}$ \\
\hline 9 & Tech III + Bio BS & $72 \mathrm{Ea}$ & $34 \mathrm{Fb}$ & $80 \mathrm{Ea}$ & $60 \mathrm{Fb}$ & $168.83 \mathrm{Fa}$ & $283.23 \mathrm{Fb}$ \\
\hline 10 & Tech IV + Bio OF & $87 \mathrm{Ba}$ & $78 \mathrm{Bb}$ & $93 \mathrm{Ba}$ & $88 \mathrm{Ab}$ & 134.74 Da & $166.95 \mathrm{Bb}$ \\
\hline 11 & Tech IV + Bio BS & $86 \mathrm{Ba}$ & $75 \mathrm{Cb}$ & $84 \mathrm{Da}$ & $81 \mathrm{Cb}$ & $149.45 \mathrm{Ea}$ & $189.34 \mathrm{Db}$ \\
\hline 12 & Tech V + Bio OF & $85 \mathrm{Ca}$ & $78 \mathrm{Bb}$ & $95 \mathrm{Ba}$ & $85 \mathrm{Bb}$ & 135.79 Da & $165.87 \mathrm{Bb}$ \\
\hline 13 & Tech V + Bio BS & $80 \mathrm{Da}$ & $72 \mathrm{Cb}$ & $83 \mathrm{Da}$ & $79 \mathrm{Cb}$ & $148.64 \mathrm{Ea}$ & $174.18 \mathrm{Cb}$ \\
\hline & Mean & 85 & 72 & 90 & 80.77 & 126.51 & 181.98 \\
\hline & \multirow{2}{*}{ Treatment } & \multicolumn{2}{|c|}{$\mathrm{AA}(\%)$} & \multicolumn{2}{|c|}{ FE (\%) } & \multicolumn{2}{|c|}{ SDB (g) } \\
\hline & & High vigor & Low vigor & High vigor & Low vigor & High vigor & Low vigor \\
\hline 1 & Control & $75 \mathrm{Aa}$ & $62 \mathrm{Ab}$ & $92 \mathrm{Aa}$ & $81 \mathrm{Ab}$ & $0.1851 \mathrm{Aa}$ & $0.1441 \mathrm{Ab}$ \\
\hline 2 & Bio OF & $76 \mathrm{Aa}$ & $61 \mathrm{Ab}$ & $90 \mathrm{Aa}$ & $82 \mathrm{Ab}$ & $0.1862 \mathrm{Aa}$ & $0.1410 \mathrm{Ab}$ \\
\hline 3 & Bio BS & $74 \mathrm{Aa}$ & $59 \mathrm{Bb}$ & $87 \mathrm{Ba}$ & $76 \mathrm{Bb}$ & $0.1891 \mathrm{Aa}$ & $0.0832 \mathrm{Ab}$ \\
\hline 4 & Tech I + Bio OF & $70 \mathrm{Ba}$ & $54 \mathrm{Cb}$ & $84 \mathrm{Ba}$ & $75 \mathrm{Bb}$ & $0.0852 \mathrm{Ba}$ & $0.0522 \mathrm{Db}$ \\
\hline 5 & Tech I + Bio BS & $65 \mathrm{Ca}$ & $48 \mathrm{Db}$ & $81 \mathrm{Ca}$ & $70 \mathrm{Db}$ & $0.0562 \mathrm{Da}$ & $0.0450 \mathrm{~Eb}$ \\
\hline 6 & Tech II + Bio OF & $62 \mathrm{Da}$ & $55 \mathrm{Cb}$ & $87 \mathrm{Ba}$ & $73 \mathrm{Cb}$ & $0.0845 \mathrm{Ba}$ & $0.0676 \mathrm{Cb}$ \\
\hline 7 & Tech II + Bio BS & $65 \mathrm{Ca}$ & $47 \mathrm{Db}$ & $82 \mathrm{Ca}$ & $68 \mathrm{Db}$ & $0.0643 \mathrm{Ca}$ & $0.0574 \mathrm{Db}$ \\
\hline 8 & Tech III + Bio OF & $55 \mathrm{Fa}$ & $35 \mathrm{~Eb}$ & $80 \mathrm{Ca}$ & $67 \mathrm{Db}$ & $0.0463 \mathrm{Ea}$ & $0.0370 \mathrm{Fb}$ \\
\hline 9 & Tech III + Bio BS & $35 \mathrm{Ga}$ & $27 \mathrm{Fb}$ & $73 \mathrm{Ea}$ & $43 \mathrm{~Eb}$ & $0.0276 \mathrm{Fa}$ & $0.0281 \mathrm{~Gb}$ \\
\hline 10 & Tech IV + Bio OF & $66 \mathrm{Ca}$ & $58 \mathrm{Bb}$ & $86 \mathrm{Ba}$ & $76 \mathrm{Bb}$ & $0.0876 \mathrm{Ba}$ & $0.0801 \mathrm{Bb}$ \\
\hline 11 & Tech IV + Bio BS & $67 \mathrm{Ca}$ & $46 \mathrm{Db}$ & $82 \mathrm{Ca}$ & $72 \mathrm{Cb}$ & $0.0654 \mathrm{Ca}$ & $0.0683 \mathrm{Cb}$ \\
\hline 12 & Tech V + Bio OF & $61 \mathrm{Da}$ & $59 \mathrm{Bb}$ & $85 \mathrm{Ba}$ & $77 \mathrm{Bb}$ & $0.0865 \mathrm{Ba}$ & $0.0692 \mathrm{Cb}$ \\
\hline 13 & Tech V + Bio BS & $57 \mathrm{Ea}$ & $49 \mathrm{Db}$ & $77 \mathrm{Da}$ & $68 \mathrm{Db}$ & $0.0656 \mathrm{Ca}$ & $0.0585 \mathrm{Db}$ \\
\hline Mean & & 66 & 51 & 84 & 71 & 0.0946 & 0.0753 \\
\hline
\end{tabular}

Tech I: pyraclostrobin + thiophanate-methyl + fipronil; Tech II: (carbendazim + thiram) + (imidacloprid + thiodicarb); Tech III: similar to Tech II, but using a 1.4-fold higher dose of imidacloprid + thiodicarb; Tech IV: (carbendazim + thiram) + chlorantraniliprole; Tech V: (metalaxyl-m + fludioxonil) + thiamethoxam. According to the Scott-Knott grouping criterion, means followed by the same uppercase letter in the column belong to the same group at $5 \%$ probability. Means followed by the same lowercase letters in the line do not differ from each other by the F-test at a $5 \%$ probability level. 
thiodicarb, solution volumes of up to $1400 \mathrm{~mL} \cdot \mathrm{kg}^{-1}$ (200 or 400 $\mathrm{mL}$ lower than those of Technologies II and III, respectively) did not cause reductions in the physiological quality when seeds were analyzed immediately after the treatment. However, these authors used imidacloprid/thiodicarb doses ranging from 2.5 to 3.5 times lower than those used in Technologies II and III, respectively. On the other hand, with the same fungicide and insecticide doses of Technology II, Pereira et al. (2016) reported that volumes of $1800 \mathrm{~mL} .100$ $\mathrm{kg}^{-1}$ of seeds, the same as that of Technology III, caused a reduction in the physiological potential of soybean seeds although they did not compromise the commercialization potential of lots since germination reached or exceeded $80 \%$ (Brasil, 2013).

Although in a lower proportion than in deteriorated seeds, lots of a high physiological quality also present reductions in germination and vigor as solution volume increases (Segalin et al., 2013; Santos et al., 2018). In this sense, Brzezinski et al. (2017) observed that the susceptibility of seeds to damage caused by these high solution volumes is related to the initial vigor of the lot. In this case, with the gradual addition of other products to the solution (inoculant, biostimulant, polymers, and micronutrients), high-vigor seeds tolerated twice the volume tolerated by low-vigor seeds. Similar to the results found in our study, the detrimental effects on seed germination and vigor were more evident in low-vigor seeds (Table 2).

In addition to a lower reserve mobilization capacity, deteriorated seeds probably have limitations in the cellular reorganization process (Marcos-Filho and França-Neto, 2017). This characteristic is essential to the maintenance of the selective permeability of membranes and prevents the excessive exudation of electrolytes to the exterior of the cells, working as a barrier of restriction to the passage of solutes during soaking (Marcos-Filho, 2015).

For high-vigor seeds, regardless of the adopted biostimulant application strategy, only Technology III did not reach or surpassed the percentage of $80 \%$ of normal seedlings, which is necessary for the commercialization of soybean seeds in Brazil (Brasil, 2013). However, for the lowvigor lot, only the control (treatment 1) and treatment 2 (Bio $\mathrm{OF})$ reached or exceeded this minimum level.

When comparing germination, emergence in sand, electrical conductivity, accelerated aging, field emergence, and seedling dry biomass, obtained in the treatment pairs that make up each technology described in Table $1(\mathrm{~T} 4 \times \mathrm{T} 5, \mathrm{~T} 6 \times$ $\mathrm{T} 7, \mathrm{~T} 8 \times \mathrm{T} 9, \mathrm{~T} 10 \times \mathrm{T} 11$, and T12 $\times \mathrm{T} 13)$, a higher physiological performance was obtained when the biostimulant was applied before seed analysis (Table 2). Exceptions were observed in Technology IV in the tests of germination and accelerated aging in the group of high-vigor seeds, in which the on-farm and early applications were equivalent to each other, as well as in Technology II, in which the early strategy stood out when compared to the on-farm in the accelerated aging test in the group of high-vigor seeds (Table 2).

For high-vigor seeds not treated with agricultural pesticides (treatments 2 and 3), except for the tests of electrical conductivity and seedling dry biomass, both biostimulant application strategies were equivalent from the point of view of physiological quality (Table 2). However, in the seeds treated with fungicides and insecticides, at both levels of initial vigor, the on-farm application positively stood out on the early application in the tests of accelerated aging, emergence in sand, seedling dry biomass, and electrical conductivity, regardless of the technology or initial vigor. In contrast, no statistical difference was found between the strategies for Technology II in the initial high-vigor lot.

The tendency of superior results of the on-farm strategy is probably due to the inexistence of a storage period. According to Santos et al. (2018), the water predominance of solutions is a determining factor in the rate of seed deterioration, especially during storage. The deterioration and consequent loss of seed viability is an inevitable, continuous, and irreversible process. However, as observed in this study (Table 2), the storage potential of a seed lot is also determined by its initial germination and vigor (Marcos Filho, 2015).

In this scenario, Krzyzanowski and França-Neto (2001) point out that the innumerable physical, physiological, and biochemical changes resulting from seed aging can be potentiated or reduced by the combination of temperature, relative air humidity, and seed water content. In the case of soybean seeds, a critical factor is that, in general, after processing, the lots are stored in environments without specific atmospheric controls, exposing the seeds to adverse conditions characterized by daily fluctuations in relative humidity and temperature, which accelerate seed aging and favor its deterioration by fungi and pests (Fessel et al., 2003).

In relation to crop yield (Table 3), superior results of stand and yield were observed in the control (Bio FL) and in treatments 2 (Bio OF), 3 (Bio BS), and 4 (Technology I + Bio OF), signaling that the association of Technology I (used on the day before the analyses) with the on-farm biostimulant application provides results of yield statistically equivalent to that of seeds not treated with pesticides, regardless of the used application strategy (foliar in the V5 stage, on-farm or early). On the one hand, inferior results of yield (Table 3) were obtained with Technology I (treatment 5) when using the early strategy, on the other hand, no adverse physiological effects of the used solution were observed on crop yield in the on-farm application. 
As in the laboratory experiment, carbendazim/thiram + imidacloprid/thiodicarb-based mixtures (Technologies II and III) presented the lowest values of stand and one thousandgrain weight, especially in the highest solution volume (1800 $\mathrm{mL} . \mathrm{kg}^{-1}$, Technology III). When comparing the treatment pairs contained in each technology (Table 1), the on-farm biostimulant application, either via foliar in V5 (treatment 1) or via seeds (treatments 4, 6, 10, and 12), provided higher values when compared to those in which the regulator was applied early (treatments 5, 7, and 13), except for Technology IV, in which both strategies were statistically equivalent to each other. However, two exceptions were observed (Table 3): in the seeds not treated with pesticides, in which treatments 1 (Bio FL) and 2 (Bio OF) were equivalent to each other in the stand, and in Technology IV (treatments 10 and 11), in which no differences were observed for this variable.

For the one thousand-grain weight, seeds not coated with pesticides (treatments 1,2, and 3), as well as those of the on-farm treatment associated with Technology I (treatment 4) positively stood out among all the tested interactions. For Technologies

Table 3. Means for stand, one thousand-grain weight (TGW), and yield of the high-vigor lot of soybean seeds of the cultivar BMX Potência RR as a function of the treatment on-farm with biostimulant just before sowing (Bio OF) and early application of biostimulant via industrial treatment at 60 days before experiment setup (Bio BS).

\begin{tabular}{clccc}
\hline & Treatment & $\begin{array}{c}\text { Stand } \\
\left(\text { plants. } \mathrm{m}^{-2}\right)\end{array}$ & $\begin{array}{c}\text { TGW } \\
(\mathrm{g})\end{array}$ & $\begin{array}{c}\text { Yield } \\
\left(\mathrm{kg} . \mathrm{ha}^{-1}\right)\end{array}$ \\
\hline 1 & Control & $18.43 \mathrm{~A}$ & $163.01 \mathrm{~A}$ & $3.089 \mathrm{~A}$ \\
2 & Bio OF & $18.40 \mathrm{~A}$ & $162.92 \mathrm{~A}$ & $3.135 \mathrm{~A}$ \\
3 & Bio BS & $18.61 \mathrm{~A}$ & $162.81 \mathrm{~A}$ & $3.040 \mathrm{~A}$ \\
4 & Tech I + Bio OF & $18.75 \mathrm{~A}$ & $163.12 \mathrm{~A}$ & $3.061 \mathrm{~A}$ \\
5 & Tech I + Bio BS & $17.07 \mathrm{~B}$ & $162.97 \mathrm{~B}$ & $2.937 \mathrm{~B}$ \\
6 & Tech II + Bio OF & $16.27 \mathrm{C}$ & $161.87 \mathrm{D}$ & $2.918 \mathrm{~B}$ \\
7 & Tech II + Bio BS & $15.20 \mathrm{D}$ & $161.77 \mathrm{D}$ & $2.723 \mathrm{C}$ \\
8 & Tech III + Bio OF & $14.59 \mathrm{D}$ & $162.48 \mathrm{~B}$ & $2.441 \mathrm{D}$ \\
9 & Tech III + Bio BS & $13.37 \mathrm{E}$ & $162.54 \mathrm{~B}$ & $2.132 \mathrm{E}$ \\
10 & Tech IV + Bio OF & $18.00 \mathrm{~A}$ & $162.24 \mathrm{~B}$ & $2.923 \mathrm{~B}$ \\
11 & Tech IV + Bio BS & $17.95 \mathrm{~A}$ & $162.32 \mathrm{~B}$ & $2.756 \mathrm{C}$ \\
12 & Tech V + Bio OF & $17.10 \mathrm{~B}$ & $162.36 \mathrm{~B}$ & $2.905 \mathrm{~B}$ \\
13 & Tech V + Bio BS & $15.40 \mathrm{D}$ & $162.16 \mathrm{C}$ & $2.697 \mathrm{C}$ \\
\hline & Mean & 16.86 & 162.51 & 2.827 \\
\hline
\end{tabular}

Tech I: pyraclostrobin + thiophanate-methyl + fipronil; Tech II: (carbendazim + thiram) + (imidacloprid + thiodicarb); Tech III: similar to Tech II, but using a 1.4-fold higher dose of imidacloprid + thiodicarb; Tech IV: (carbendazim + thiram) + chlorantraniliprole; Tech V: (metalaxyl-m + fludioxonil) + thiamethoxam. According to the Scott-Knott grouping criterion, means followed by the same uppercase letter in the column belong to the same group at $5 \%$ probability.
II, III, and IV, however, no differences were observed between their respective pairs (Table 3), thus indicating that the tested biostimulant application strategies were equivalent from the point of view of the one thousand-grain weight. A different behavior was observed in Technologies I and V, in which the on-farm treatments (treatments 4 and 12, respectively) showed a positive effect in relation to their homologs (treatments 5 and 13 , respectively).

Finally, regarding the grain yield, the control (treatment 1), treatments 2 (Bio OF), 3 (Bio BS), and 4 (Technology I + Bio $\mathrm{OF}$ ) showed a positive effect in relation to the others (Table 3), whereas the lowest yield values were observed in the treatments with carbendazim/thiram + imidacloprid/thiodicarb with a solution volume of $1800 \mathrm{~mL} .100 \mathrm{~kg}^{-1}$ of seeds. Thus, similar to the findings in the laboratory experiment (Table 2), seeds industrially treated with fungicides and insecticides the day before sowing and submitted to the on-farm biostimulant application presented a superior agronomic performance for yield (Table 3).

\section{Conclusions}

The on-farm biostimulant application in soybean seeds not coated with fungicides and insecticides did not affect the physiological seed quality throughout the storage. However, when the biostimulant was added to solutions of industrial treatments, superior results of germination, vigor, and yield were obtained with its on-farm application.

\section{Acknowledgements}

To Coordenação de Aperfeiçoamento de Pessoal de Nivel Superior-CAPES, for the scholarships and resources for research development.

\section{References}

AVELAR, S.A.G.; BAUDET, L.; PESKE, S.T.; LUDWIG, M.P.; RIGO, G.A.; CRIZEL, R.L.; OLIVEIRA, S. Armazenamento de sementes de soja tratadas com fungicida, inseticida e micronutriente e recobertas com polímeros líquido e em pó. Ciência Rural, v.41, n.10, p.1719-1725, 2011. http://dx.doi.org/10.1590/S010384782011005000130

BANZATTO, D.A.; KRONKA, S.N. Experimentação agrícola. 4.ed. Jaboticabal: FUNEP, 2008. p.23-52.

BERTOLIN, D.C.; SÁ, M.E.; ARF, O.; FURLANI JUNIOR, E.; COLOMBO, A.S.; CARVALHO, F.L.B.M. Aumento da produtividade de soja com a aplicação de bioestimulantes. Bragantia, v.69, n.2, p.339347, 2010. https://dx.doi.org/10.1590/S0006-87052010000200011 
BRASIL. Ministério da Agricultura, Pecuária e Abastecimento. Regras para análise de sementes. Ministério da Agricultura, Pecuária e Abastecimento. Secretaria de Defesa Agropecuária. Brasília: MAPA/ACS, 2009. 395p.

BRASIL. Ministério da Agricultura, Pecuária e Abastecimento. Instrução Normativa n.45 de 17 de setembro de 2013. Anexo XXIII - Padrões para produção e comercialização de sementes de soja. Diário Oficial da República Federativa do Brasil, Poder Executivo, Brasília, DF, 2013. 39p.

BRZEZINSKI, C.R.; ABATI, J.; HENNING, F.A.; HENNING, A.A.; FRANÇA-NETO, J.B.; KRZYZANOWSKI, F.C.; ZUCARELI, C. Spray volumes in the industrial treatment on the physiological quality of soybean seeds with different levels of vigor. Journal of Seed Science, v.39, n.2, p.174-181, 2017. https://dx.doi.org/10.1590/2317$1545 \mathrm{v} 39 \mathrm{n} 2175179$

CAVIGLIONE, J.H.; KIIHL, L.R.B.; CARAMORI, P.H.; OLIVEIRA, D. Cartas climáticas do Paraná. Londrina: IAPAR, 2000. CD ROM.

DAN, L.G.M.; DAN, H.A.; BARROSO, A.L.L.; BRACCINI, A.L. Qualidade fisiológica de sementes de soja tratadas com inseticidas sob efeito do armazenamento. Revista Brasileira de Sementes, v.32, n.2, p.131-139, 2010. http://dx.doi.org/10.1590/S0101-31222010000200016

DAN, L.G.M.; DAN, H.A.; ALBRECHT, L.P.; RICCI, T.T.; PICCININ, G.G. Desempenho de sementes de soja tratadas com inseticidas e submetidas a diferentes períodos de armazenamento. Revista Brasileira de Ciências Agrárias, v.6, n.2, p.215-222, 2011. http://dx.doi.org/10.5039/agraria.v6i2a939

EMBRAPA. Tecnologias de produção de soja - Região Central do Brasil 2014. Londrina: Embrapa Soja, Sistemas de Produção / Embrapa Soja, n.16, 2013a. https://www.embrapa.br/busca-depublicacoes/-/publicacao/975595/tecnologias-de-producao-de-soja--regiao-central-do-brasil-2014

EMBRAPA. Sistema brasileiro de classificação de solos. 3.ed. Brasília, 2013b. 353p.

FESSEL, S.A.; MENDONÇA, E.A.F.; CARVALHO, R.V.; VIEIRA, R.D. Efeito do tratamento químico sobre a conservação de sementes de milho durante o armazenamento. Revista Brasileira de Sementes, v.25, n.1, p.25-28, 2003. http://www.scielo.br/pdf/rbs/v25n1/19626.pdf

FRANÇA-NETO, J.B.; HENNING, A.A.; KRZYZANOWSKI, F.C.; HENNING, F.A.; LORINI, I. Adoção do tratamento industrial de sementes de soja no Brasil, safra 2014/15. Informativo ABRATES, v.25, n.1, p.26-29, 2015. http://www.abrates.org.br/img/ informations/644f0c7f-9b60-4872-ba90-78622c333dd0_IA $\% 20$ v25\%20n1.pdf

KRZYZANOWSKI, F.C.; FRANÇA-NETO, J.B. Vigor de sementes. Informativo ABRATES, v.11, n.3, p.81-84, 2001.

MARCOS-FILHO, J. Teste de envelhecimento acelerado. In: KRZYZANOWSKI, F. C.; VIEIRA, R. D.; FRANÇA-NETO, J.B. (Ed.). Vigor de sementes: conceitos e testes. Londrina: ABRATES, 1999. p.1-24.
MARCOS-FILHO, J. Fisiologia de sementes de plantas cultivadas. 2.ed. Londrina: ABRATES, 2015. 659p.

MARCOS FILHO, J.; FRANÇA-NETO, J.B. Vigor de sementes: um componente de qualidade em permanente evolução. SEED News, v.21, n.5, p.42-49, 2017. https://seednews.com.br/edicoes/28-onegocio-de-sementes-nos-eua-xxi-\%7C-01-janeiro-2017

MENTEN, J.O.; MORAES, M.H.D. Tratamento de sementes: histórico, tipos, características e benefícios. Informativo ABRATES, v.20, n.3, p.52-71, 2010. https://www.abrates.org.br/informativoabrates/edicao

NAKAGAWA, J. Testes de vigor baseados no desempenho das plântulas. In: KRZYZANOWSKI, F.C.; VIEIRA, R.D.; FRANÇANETO, J.B. (Ed.). Vigor de sementes: conceitos e testes. Londrina: ABRATES, 1999. p.1-24.

PEREIRA, L.C.; GARCIA, M.M.; BRACCINI, A.L.; PIANA, S.C.; FERRI, G.C.; MATERA, T.C.; FELBER, P.H.; MARTELI, D.C.V. Efeito da adição de biorregulador ao tratamento industrial sobre a qualidade de sementes de soja (Glycine $\max$ (L.) Merr.) aos sessenta dias de armazenamento convencional. Revista Colombiana de Investigaciones Agroindustriales, v.3, n.2, p.15-22, 2016. https://doi. org/10.23850/issn.2422-0582

PEREIRA, L.C.; GARCIA, M.M.; BRACCINI, A.L; FERRI, G.C.; SUZUKAWA, A.K; MARTELI, D.C.V.; MATERA, T.C.; PEREIRA, R.C.; CORREIA, L.V. Physiological potential of soybean seeds over storage after industrial treatment. Journal of Seed Science, v.40, n.3, p.26-33, 2018. http://dx.doi.org/10.1590/2317-1545v40n3185104

SALDANA, J. The coding manual for qualitative researchers. 1 ed. Washington: Sage Publications Ltd., 2009. 224p.

SEGALIN, S.R.; BARBIERI, A.P.P.; HUTH, C.; BECHE, M.; MATTIONI, N.M.; METZ, L.M. Physiological quality of soybean seeds treated with different spray volumes. Journal of Seed Science, v.35, n.4, p.501-509, 2013. http://dx.doi.org/10.1590/S2317-15372013000400012

SANTOS, S.F.; CARVALHO, E.R.; ROCHA, D.K.; NASCIMENTO, R.M. Composition and volumes of slurry in soybean seeds treatment in the industry and physiological quality during storage. Journal of Seed Science, v.40, n.1, p.67-74, 2018. http://dx.doi. org/10.1590/2317-1545v40n1185370

STRIEDER, G.; FOGUESATTO, R.J.; GADOTTI, G.I.; LUZ, M.L.G.S.; LUZ, C.A.S.; GOMES, M.C.; SCHERER, V.S. Estudo técnico e de cenários econômicos para implantação de uma unidade de tratamento industrial de sementes de soja e trigo. Informativo ABRATES, v.24, n.3, p.118-123, 2014. http://www.abrates.org.br/ informativo-abrates/edicao/17

TAIZ, L.; ZEIGER, E. Fisiologia vegetal. 5.ed. Porto Alegre: Artmed, 2013. 954p.

ZAMBON, S. Aspectos importantes do tratamento de sementes. Informativo ABRATES, v.23, n.2, p.26, 2013. https://www.abrates. org.br/img/informations/73cc19c0-13b9-46dc-8b17-2cd0f519678a_ IA $\% 20 v 23 \% 20 \mathrm{n} 2 \% 20-\% 20 \mathrm{CBSementes.pdf}$ 